J. Dairy Sci. 99:8203-8215

http://dx.doi.org/10.3168/jds.2016-11437

(C) American Dairy Science Association ${ }^{\circledR}, 2016$.

\title{
Whole-genome scan to detect quantitative trait loci associated with milk protein composition in 3 French dairy cattle breeds
}

\author{
M. P. Sanchez, ${ }^{* 1}$ A. Govignon-Gion, ${ }^{\star} \dagger$ M. Ferrand,† M. Gelé, † D. Pourchet, $¥$ Y. Amigues, $§$ S. Fritz, ${ }^{*} \#$ \\ M. Boussaha, ${ }^{*}$ A. Capitan, ${ }^{\star} \#$ D. Rocha, ${ }^{*}$ G. Miranda, ${ }^{*}$ P. Martin, ${ }^{*}$ M. Brochard,† and D. Boichard* \\ *GABI, INRA, AgroParisTech, Université Paris Saclay, F-78350 Jouy-en-Josas, France \\ †Institut de l'Elevage, F-75012 Paris, France \\ łEntreprise de Conseil en Elevage Doubs, Territoire de Belfort, F-25640 Roulans, France \\ §Labogena DNA, F-78350 Jouy en Josas, France \\ \#Allice, F-75012 Paris, France
}

\section{ABSTRACT}

In the context of the PhénoFinLait project, a genome-wide analysis was performed to detect quantitative trait loci (QTL) that affect milk protein composition estimated using mid-infrared spectrometry in the Montbéliarde (MO), Normande (NO), and Holstein (HO) French dairy cattle breeds. The 6 main milk proteins ( $\alpha$-lactalbumin, $\beta$-lactoglobulin, and $\alpha_{\mathrm{S1}^{-}}$, $\alpha_{S 2^{-}}, \beta$-, and $\kappa$-caseins) expressed as grams per $100 \mathrm{~g}$ of milk (\% of milk) or as grams per $100 \mathrm{~g}$ of protein (\% of protein) were estimated in 848,068 test-day milk samples from 156,660 cows. Genotyping was performed for 2,773 MO, 2,673 $\mathrm{NO}$, and 2,208 $\mathrm{HO}$ cows using the Illumina BovineSNP50 BeadChip (Illumina Inc., San Diego, CA). Individual test-day records were adjusted for environmental effects and then averaged per cow to define the phenotypes analyzed. Quantitative trait loci detection was performed within each breed using a linkage disequilibrium and linkage analysis approach. A total of 39 genomic regions distributed on 20 of the 29 Bos taurus autosomes (BTA) were significantly associated with milk protein composition at a genome-wide level of significance in at least 1 of the 3 breeds. The 9 most significant QTL were located on BTA2 (133 Mbp), BTA6 (38, 47, and $87 \mathrm{Mbp})$, BTA11 (103 Mbp), BTA14 (1.8 Mbp), BTA20 (32 and $58 \mathrm{Mbp}$ ), and BTA29 (8 Mbp). The BTA6 (87 Mbp), BTA11, and BTA20 (58 Mbp) QTL were found in all 3 breeds, and they had highly significant effects on $\kappa$-casein, $\beta$-lactoglobulin, and $\alpha$-lactalbumin, expressed as a percentage of protein, respectively. Each of these QTL explained between 13\% (BTA14) and 51\% (BTA11) of the genetic variance of the trait. Many other QTL regions were also identified in at least one breed. They were located on 14 additional chromosomes $(1,3,4,5,7,15,17,19$,

Received May 10, 2016.

Accepted June 16, 2016.

${ }^{1}$ Corresponding author: marie-pierre.sanchez@jouy.inra.fr
$21,22,24,25,26$, and 27 ), and they explained 2 to $8 \%$ of the genetic variance of 1 or more protein composition traits. Concordance analyses, performed between QTL status and sequence-derived polymorphisms from 13 bulls, revealed previously known causal polymorphisms in $L G B$ (BTA11) and GHR (BTA20 at $32 \mathrm{Mbp}$ ) and excluded some other previously described mutations. These results constitute a first step in identifying causal mutations and using routinely collected mid-infrared predictions in future genomic selection programs to improve bovine milk protein composition.

Key words: dairy cattle, mid-infrared spectrometry, protein composition, quantitative trait loci

\section{INTRODUCTION}

Bovine milk contains 3 to $4 \%$ protein, which consists of about $80 \%$ caseins and $20 \%$ whey proteins. The relative fractions of protein play a key role in determining the functional properties of milk, such as clotting and cheese yield (Wedholm et al., 2006). The protein composition of bovine milk varies with different environmental factors (herd, season, stage of lactation, diet, and so forth), but it is mostly determined by genetic factors (Schopen et al., 2009; Bonfatti et al., 2011a; Gebreyesus et al., 2016).

Accurate genetic analyses of milk protein composition require large-scale studies. To date, these have been hampered by the complicated nature and cost of individual protein measurements in milk. Reference methods such as capillary zone electrophoresis are time consuming and expensive and have therefore only been applied to small or moderate numbers of milk samples. The largest QTL study, performed by Schopen et al. (2011), used more than 1,700 individual protein measurements obtained by liquid chromatography. More recently, mid-infrared (MIR) spectrometry has been shown to be useful for predicting milk protein composition (Bonfatti et al., 2011b; Ferrand et al., 2012), and it offers an alternative method for large-scale analyses. 
Combined with high-throughput genotyping technologies, identifying the genomic regions responsible for genetic variation (QTL) in individual protein contents and accounting for these traits in genomic selection programs are now possible. PhénoFinLait is a major project that was initiated in 2008 to study milk in cattle, sheep, and goat dairy species (Gelé et al., 2014). One of its objectives was to dissect the genetic architecture of individual milk protein composition. In cattle, MIR predictive equations were derived from 450 reference samples analyzed using reverse-phase liquid chromatography. They were applied to the Montbéliarde (MO), Normande (NO), and Holstein (HO) French dairy breeds (Ferrand et al., 2012). The contents of the 6 major bovine milk proteins $\left(\alpha_{\mathrm{S}^{-}}, \alpha_{\mathrm{S} 2^{-}}, \beta-\right.$, and $\kappa-\mathrm{CN}$ and $\alpha$-LA and $\beta$-LG whey proteins) could be predicted with satisfactory accuracy. An initial study to estimate genetic parameters of these traits revealed relatively high heritability coefficients (Brochard et al., 2013) that were close to the values calculated from the protein contents estimated using a reference method (Schopen et al., 2009). These results suggested that the predictive accuracy of MIR protein content determinations was sufficiently accurate for genetic investigations.

To date, only one whole-genome association study using high-density SNP genotyping has been performed on milk protein composition in dairy cattle (Schopen et al., 2011). Those authors analyzed milk protein composition using capillary zone electrophoresis on 1,713 test-day samples from Dutch Holstein-Friesian cows. The present study reports the results of a wholegenome scan carried out on the lactation records of 2,773 $\mathrm{MO}, 2,673 \mathrm{NO}$, and 2,208 $\mathrm{HO}$ cows to identify QTL affecting individual protein composition predicted from MIR spectra. In addition, to validate effects of 10 known candidate mutations (located in 5 distinct genomic regions), concordance analyses between bull genotypes and QTL were carried out using data from the 1,000 bull genome project (Daetwyler et al., 2014).

\section{MATERIALS AND METHODS}

\section{Animals, Milk Samples, and Phenotypic Data}

In total, MIR spectra were collected on 848,068 milk samples from 156,660 cows collected between November 2009 and August 2012. These cows belonged to the 3 main French dairy breeds ( $\mathrm{MO}, \mathrm{NO}$, and $\mathrm{HO}$ ) and were selected according to their number of milk records. They were also distributed across 1,043 herds covering a broad range of geographical locations (16 small regions) and production systems (grass or maize silage, high or low input, conventional or organic, and so forth). In addition, to ensure broad genetic diversity, a list of AI bulls was set and herds were selected to maximize the number of daughters (hereinafter referred to as PhénoFinLait or PFL cows) born from these bulls and experiencing their first or second calving during the winter of 2009-2010. The MIR spectra were recovered from 5,3 , and 5 milk analysis laboratories for $\mathrm{MO}, \mathrm{NO}$, and $\mathrm{HO}$ cows, respectively, and all other information was retrieved from the National Information System. The whole milk protein content (PC) and milk protein composition were predicted using MIR spectra and equations previously derived by Ferrand et al. (2012). Individual protein contents were predicted for the 6 main milk proteins: $\alpha-\mathrm{LA}$ and $\beta-\mathrm{LG}$ whey proteins and $\alpha_{\mathrm{S1}^{-}}, \alpha_{\mathrm{S} 2^{-}}, \beta-$, and $\kappa-\mathrm{CN}$ and expressed as grams per 100 g milk (\% of milk) or as grams per $100 \mathrm{~g}$ protein (\% of protein). A total of 13 traits were analyzed: PC and the 6 proteins expressed as a percentage of milk and as a percentage of protein.

For each trait, a single phenotype per cow and across lactations was used in the QTL analysis. This phenotype was defined as the average per cow of test-day data, adjusted for all nongenetic effects. These nongenetic effects were estimated with the following breedspecific single trait model:

$$
\mathbf{y}=\mu+\mathbf{X} \boldsymbol{\beta}+\mathbf{Z} \mathbf{a}+\mathbf{Z} \mathbf{p}+\mathbf{e}
$$

where $\mu$ is the overall mean, $\mathbf{y}$ is the vector of test-day observations, $\mathbf{a} \sim N\left(0, \mathbf{A} \sigma_{a}^{2}\right)$ is the vector of random genetic effects, $\mathbf{p} \sim N\left(0, \mathbf{I} \sigma_{p}^{2}\right)$ is the vector of random permanent environmental effects, and $\mathbf{e} \sim N\left(0, \mathbf{I} \sigma_{e}^{2}\right)$ is the vector of random residual effects, $\mathbf{X}$ and $\mathbf{Z}$ are incidence matrices, $\mathbf{A}$ is the relationship matrix among individuals, and $\mathbf{I}$ is the identity matrix. Variances $\sigma_{a}^{2}$, $\sigma_{p}^{2}$, and $\sigma_{e}^{2}$ are the additive genetic, permanent environmental, and residual variances, respectively. The vector $\boldsymbol{\beta}$ included the fixed effects of herd $\times$ test-day, parity $\times$ stage of lactation (63 levels), year $\times$ month of calving (34 levels), and spectrometer $\times$ test-month (102 levels). This model was applied to the first 3 lactations with at least 3 test-day records per lactation during the study period. In total, data from $344,542,73,347$, and 89,730 test-day records were analyzed, corresponding to 54,676 $\mathrm{MO}, 15,550 \mathrm{NO}$, and 17,983 $\mathrm{HO}$ cows, respectively (Table 1). All estimates were obtained using Genekit software (Ducrocq, 1998).

\section{Genotyping}

A total of 8,010 PFL cows $(2,967 \mathrm{MO}, 2,737 \mathrm{NO}$, and 2,306 $\mathrm{HO}$ ) were genotyped with the Illumina BovineSNP50 BeadChip (Illumina Inc., San Diego, CA) 
or, for a small group of them $(6 \%)$, with the Illumina BovineLD BeadChip and subsequently imputed to Illumina BovineSNP50 genotypes. These cows were selected from the initial list of PFL cows by maximizing the number of test-days with MIR information while maintaining a good balance across breeds and sires. Quality control was applied to SNP mapped to the 29 autosomes (UMD3.1 assembly; Zimin et al., 2009). First, only samples with a call rate $>95 \%$ were retained. Second, markers with a call frequency $<90 \%$, a minor allele frequency $<5 \%$, or genotype frequencies deviating from the Hardy-Weinberg equilibrium $(P<$ 1.E-4) were removed. After filtering, imputation and phasing were performed using DagPhase (Druet and Georges, 2010) as described by Boichard et al. (2012). Overall, 36,912, 37,363, and 39,683 SNP for 2,773 MO, 2,673 NO, and 2,208 HO cows, respectively, were used for QTL detection analyses (Table 1).

\section{QTL Detection Analyses}

Because of the strong family structure in the design with planned half-sib families, we applied an approach maximizing detection power by accounting for linkage information within a family. This approach was an alternative to a simple association study in which the SNP association statistics have to be corrected for family structure (e.g., by using a genomic control). Therefore, after phase reconstruction, a linkage disequilibrium and linkage analysis approach combining the identity-by-descent method described by Meuwissen and Goddard (2000) and its extension to include linkage information (Meuwissen et al., 2002) was applied to detect QTL (Druet et al., 2008). This approach is a variance component mapping method that accounts for the transmission of haplotypes across generations and information from linkage disequilibrium between haplotypes. The method used to compute identityby-descent probabilities and haplotype clustering was described by Druet et al. (2008). Each haplotype was defined by 6 adjacent markers. Then, a model including both polygenic and haplotype cluster effects was applied:

$$
\mathbf{y}^{\prime}=\mu+\mathbf{Z}_{u} \mathbf{u}+\mathbf{Z}_{h} \mathbf{h}+\mathbf{e}
$$

where $\mathbf{y}^{\prime}$ is the vector of preadjusted records derived from Equation [1] and averaged per cow; $\mu$ is the overall mean; $\mathbf{u} \sim N\left(0, \mathbf{A} \sigma_{u}^{2}\right)$ is the vector of random polygenic effects with $\mathbf{A}$ the matrix of additive genetic relationships among individuals, identical to the $\mathbf{A}$ matrix of Equation [1], and $\sigma_{u}^{2}$ the polygenic variance; $\mathbf{h} \sim N\left(0, \mathbf{H} \sigma_{h}^{2}\right)$ is the vector of random QTL effects cor-
Table 1. Numbers of mid-infrared (MIR) spectra collected and cows in lactations 1 to 3

\begin{tabular}{lrrr}
\hline Breed & $\begin{array}{c}\text { MIR } \\
\text { spectra }\end{array}$ & Cows & $\begin{array}{c}\text { Genotyped } \\
\text { cows }\end{array}$ \\
\hline Montbéliarde & 344,542 & 54,676 & 2,773 \\
Normande & 73,347 & 15,550 & 2,673 \\
Holstein & 89,730 & 17,983 & 2,208 \\
Total & 507,619 & 88,209 & 7,654 \\
\hline
\end{tabular}

responding to haplotype clusters with $\mathbf{H}$ the identityby-descent matrix between the haplotype clusters and $\sigma_{h}^{2}$ the haplotype cluster variance; $\mathbf{e} \sim N\left(0, \mathbf{I} \sigma_{e}^{2}\right)$ is the vector of random residual effects with $\mathbf{I}$ the identity matrix and $\sigma_{e}^{2}$ the residual variance; $\mathbf{Z}_{u}$ and $\mathbf{Z}_{h}$ are incidence matrices relating phenotypes to corresponding polygenic and haplotype cluster effects, respectively.

The BLUPF90 software (Misztal et al., 2002) modified by Druet et al. (2008) was used to incorporate relationship matrices among QTL allele effects at each putative QTL position. Variance components $\left(\hat{\sigma}_{u}^{2}, \hat{\sigma}_{h}^{2}, \hat{\sigma}_{e}^{2}\right)$ were estimated maximizing likelihoods using an average information (AI)-REML approach. For each QTL, the proportion of total genetic variance due to the QTL was estimated:

$$
\frac{\hat{\sigma}_{h}^{2}}{\hat{\sigma}_{u}^{2}+\hat{\sigma}_{h}^{2}} .
$$

The presence or absence of a QTL at a given position was tested by comparing Equation [2] to a polygenic model (i.e., Equation [2] without the term $\mathbf{Z}_{h} \mathbf{h}$ ) with the likelihood-ratio test statistic (LRT):

$$
\mathrm{LRT}=-2 \ln \frac{L\left(H_{0}\right)}{L\left(H_{1}\right)}
$$

where $L\left(H_{0}\right)$ and $L\left(H_{1}\right)$ were the maximum likelihood values when parameters were equal to their REML estimated values under the polygenic model with no QTL fitted $\left(H_{0}\right)$ and under the alternative model with QTL $\left(H_{1}\right)$, respectively. The distribution of the LRT had previously been described as in between the 1-df and the 2-df chi-squared distributions (Grignola et al., 1996).

Bonferroni correction was applied to the thresholds to account for the multiple testing of our analyses. Because adjacent haplotypes present high linkage disequilibrium, only nonoverlapping haplotypes were considered to define the number of independent tests. The haplotype definition with 6 markers resulted in 6,613 tests being considered for test correction. The $5 \%$ 
genome-wide threshold of significance therefore corresponded to a nominal $P$-value of $7.6 \mathrm{E}-06(0.05 / 6,613)$. A highly conservative approach was adopted by considering a 2-df chi-squared distribution for the null hypothesis, leading to a threshold of 23.6. An even more stringent threshold was also considered to highlight the most significant QTL (LRT > 50; nominal $P$-value < 1.4E-11), corresponding to the $9.3 \mathrm{E}-08$ genome-wide threshold of significance.

\section{Concordance Analyses Between QTL and Candidate Mutations}

For highly significant QTL regions, and taking advantage of the half-sib structure, a concordance analysis (van den Berg et al., 2014) was performed in the regions of interest by comparing the sequence polymorphisms of sires with their QTL status. The following procedure was applied for each QTL region:

- Haplotype definition: In each breed, haplotypes of 15 SNP from the Bovine SNP50 BeadChip were formed considering the 14 SNP surrounding the SNP with the highest LRT value (SNPmax), that is, $7 \mathrm{SNP}$ on the left side and $7 \mathrm{SNP}$ on the right side. In the same QTL region, the 15 SNP haplotypes might differ between breeds because SNPmax was not always in exactly the same position. For each region, each sire was characterized by its 2 haplotypes.

- Determination of bull QTL status: A total of 187 bulls from the 3 breeds had daughters with phenotype and genotype data. Whole-genome sequences were available for 19 of them (Boussaha et al., 2015). The QTL status of the bulls was determined by testing the contrast between haplotype effects transmitted by a sire to his daughters. For the same bull, cows were distributed into 2 groups depending on the paternal haplotype they had received. The means of the 2 groups for the trait presenting the most significant effect in the QTL region were then compared using a $t$-test. The bull was considered to be heterozygous for the QTL if $P<0.05$, homozygous if $P>0.10$, and with an unknown genotype if $0.05<P<0.10$. This QTL status was determined for 13 bulls $(7 \mathrm{MO}, 2 \mathrm{NO}$, and $4 \mathrm{HO}$ ), based on 53 to 226 daughters per bull. The 6 other bulls had too few daughters (1-15) to properly estimate their status.

- Concordance analysis: Sequence-derived polymorphisms of these 13 bulls were extracted in candidate mutation regions from the corresponding VCF files (Boussaha et al., 2015). All 13 bulls had a high genotype quality score (30 or higher). Concordances were then determined between candidate mutations and bull QTL status in these 13 bulls. A polymorphism was considered concordant with a QTL if at least $90 \%$ of the bulls were either homozygous for both the polymorphism and the QTL or heterozygous for both the polymorphism and the QTL.

\section{RESULTS}

Accuracies, means, and standard deviations for the protein contents obtained from MIR predictions and expressed as a percentage in milk and a percentage in protein in the $\mathrm{MO}, \mathrm{NO}$, and $\mathrm{HO}$ breeds are reported in Table 2. The accuracy of the MIR predictions estimated by Ferrand et al. (2012) was greater for CN contents $\left(\mathrm{R}^{2}>80 \%\right.$ and relative error $\left.<8.4 \%\right)$ than for whey proteins $\left(59 \%<\mathrm{R}^{2}<74 \% ; 11.7 \%<\right.$ relative error $<$ $14.4 \%)$. The means and standard deviations were very similar in the 3 breeds and quite similar to the values obtained using the reference analysis method.

Numerous significant genome-wide results were obtained. In total, 6,759, 3,981, and 3,942 tests were significant at the 7.6E-06 level, and among them 3,509, 1,910 , and 1,629 exceeded the stringent level of $1.0 \mathrm{E}-11$, in the MO, NO, and $\mathrm{HO}$ breeds, respectively.

Table 2. Milk protein composition: accuracy of MIR predictions and means \pm standard deviations as a percentage of milk or as a percentage of proteins in the 3 breeds, Montbéliarde (MO), Normande (NO), and Holstein (HO)

\begin{tabular}{|c|c|c|c|c|c|c|c|c|}
\hline Trait & \multicolumn{2}{|c|}{ Accuracy $^{1}$} & \multicolumn{3}{|c|}{ As a percentage of milk } & \multicolumn{3}{|c|}{ As a percentage of proteins } \\
\hline Protein content & 1.00 & 0.73 & $3.4 \pm 0.4$ & $3.6 \pm 0.4$ & $3.3 \pm 0.4$ & - & - & - \\
\hline$\beta-\mathrm{LG}$ & 0.74 & 11.7 & $0.28 \pm 0.05$ & $0.28 \pm 0.05$ & $0.28 \pm 0.05$ & $8.25 \pm 1.12$ & $7.94 \pm 1.03$ & $8.46 \pm 1.17$ \\
\hline$\alpha_{\mathrm{S}^{-}} \mathrm{CN}$ & 0.88 & 4.7 & $0.94 \pm 0.10$ & $0.99 \pm 0.10$ & $0.92 \pm 0.11$ & $27.8 \pm 0.55$ & $27.8 \pm 0.68$ & $27.9 \pm 0.69$ \\
\hline$\alpha_{\mathrm{S}_{2}}-\mathrm{CN}$ & 0.82 & 7.5 & $0.32 \pm 0.04$ & $0.35 \pm 0.04$ & $0.32 \pm 0.04$ & $9.53 \pm 0.30$ & $9.89 \pm 0.33$ & $9.69 \pm 0.39$ \\
\hline
\end{tabular}

${ }^{1}$ Accuracy of MIR predictions ( $\mathrm{R}^{2}$ and relative error) estimated by Ferrand et al. (2012). 
Because of the high degree of linkage disequilibrium between neighboring haplotypes, significant results located within the same 4-Mbp interval were grouped into a single QTL region, regardless of the breeds or traits under study. Thirty-nine genomic regions were defined (Table 3; Figure 1), distributed over 20 of the 29 BTA. Several breeds or traits (potentially $3 \times 13=39$ breed $\times$ trait combinations) could therefore be affected by the same QTL region. By region, the number of significant breed by trait combinations ranged from 1 (for 17 QTL regions) to 29 (for the 6c QTL region). These regions were generally tightly defined, including those comprising the largest number of significant results: the 20a, 11c, 14a, and 6c QTL regions presenting 10, 19, 21 , and 29 significant results were located within intervals of about 500, 200, 400, and 1,300 kbp, respectively. Nine QTL regions mapped on BTA2, BTA6 (3 distinct regions), BTA11, BTA14, BTA20 (2 distinct regions), and BTA29 had very highly significant effects (LRT > 50) with respect to protein composition.

The effects of the QTL regions on protein composition (percentage of milk and percentage of proteins), expressed as a proportion of total genetic variance $(\% \mathbf{G V})$, are reported in Tables 4, 5, and 6 for the MO,

Table 3. List of the 39 genomic regions significantly [likelihood-ratio test statistic (LRT) >23.6] associated with milk protein composition (as a percentage of milk or as a percentage of proteins) in at least 1 of the 3 breeds (Montbéliarde, Normande, or Holstein)

\begin{tabular}{|c|c|c|c|c|c|}
\hline Region $^{1}$ & $\begin{array}{l}\text { Start } \\
\text { (Mbp) }\end{array}$ & $\begin{array}{l}\text { End } \\
(\mathrm{Mbp})\end{array}$ & $\begin{array}{c}\text { No. of } \\
\text { significant } \\
\text { tests }^{2}\end{array}$ & $\begin{array}{l}\text { LRT } \\
\max \end{array}$ & $P$-value \\
\hline 1 & 144.3 & 144.3 & 1 & 23.6 & $7.5 \mathrm{E}-06$ \\
\hline $2 a$ & 6.2 & 6.2 & 1 & 31.9 & $1.2 \mathrm{E}-07$ \\
\hline $2 b$ & 75.9 & 75.9 & 1 & 30.5 & $2.4 \mathrm{E}-07$ \\
\hline $2 c$ & 131.8 & 134.1 & 5 & 54.7 & $1.3 \mathrm{E}-12$ \\
\hline $3 a$ & 15 & 15.4 & 3 & 34.3 & $3.6 \mathrm{E}-08$ \\
\hline $3 b$ & 80.9 & 80.9 & 4 & 34.5 & $3.2 \mathrm{E}-08$ \\
\hline $4 a$ & 48.9 & 48.9 & 2 & 45.4 & $1.4 \mathrm{E}-10$ \\
\hline $4 b$ & 77.8 & 80.4 & 2 & 27.7 & $9.7 \mathrm{E}-07$ \\
\hline $5 a$ & 95 & 98.6 & 2 & 27.2 & $1.2 \mathrm{E}-06$ \\
\hline $5 b$ & 105.3 & 105.3 & 1 & 26.5 & $1.8 \mathrm{E}-06$ \\
\hline $5 c$ & 115.6 & 115.6 & 1 & 30.3 & $2.6 \mathrm{E}-07$ \\
\hline $6 a$ & 37.7 & 37.7 & 1 & 102.5 & $5.5 \mathrm{E}-23$ \\
\hline $6 b$ & 46.6 & 46.7 & 2 & 86.2 & $1.9 \mathrm{E}-19$ \\
\hline $6 c$ & 86.9 & 88.2 & 29 & 309.8 & $5.3 \mathrm{E}-68$ \\
\hline 7 & 46 & 46 & 1 & 29.8 & $3.4 \mathrm{E}-07$ \\
\hline $11 a$ & 12.7 & 12.7 & 2 & 26.5 & $1.8 \mathrm{E}-06$ \\
\hline $11 b$ & 63.1 & 63.1 & 1 & 24.1 & $5.8 \mathrm{E}-06$ \\
\hline $11 c$ & 103.2 & 103.4 & 19 & $1,865.7$ & $<1.0 \mathrm{E}-308$ \\
\hline $14 a$ & 1.7 & 2.1 & 21 & 184.7 & $7.8 \mathrm{E}-41$ \\
\hline $15 a$ & 36.4 & 36.4 & 1 & 31.5 & $1.4 \mathrm{E}-07$ \\
\hline $15 b$ & 41.6 & 41.6 & 1 & 27 & $1.4 \mathrm{E}-06$ \\
\hline $15 c$ & 46.2 & 46.2 & 1 & 23.7 & 7.1E-06 \\
\hline $15 d$ & 50.6 & 53.7 & 2 & 43.7 & $3.2 \mathrm{E}-10$ \\
\hline $17 a$ & 16.4 & 16.4 & 1 & 24.1 & $5.8 \mathrm{E}-06$ \\
\hline $17 \mathrm{~b}$ & 55.5 & 57 & 1 & 24.3 & $5.3 \mathrm{E}-06$ \\
\hline 19 & 61.1 & 61.1 & 1 & 40.1 & 2.0E-09 \\
\hline $20 a$ & 31.6 & 32.1 & 10 & 50.7 & $9.8 \mathrm{E}-12$ \\
\hline $20 b$ & 36.2 & 36.3 & 1 & 38.7 & $3.9 \mathrm{E}-09$ \\
\hline $20 c$ & 58 & 59.2 & 8 & 404.3 & $1.6 \mathrm{E}-88$ \\
\hline 21 & 40.6 & 43.1 & 2 & 25.6 & $2.8 \mathrm{E}-06$ \\
\hline $22 a$ & 47.8 & 49.4 & 2 & 37.9 & $5.9 \mathrm{E}-09$ \\
\hline $22 b$ & 54.2 & 55.2 & 2 & 28.9 & 5.3E-07 \\
\hline 24 & 58.3 & 58.3 & 2 & 30.7 & $2.2 \mathrm{E}-07$ \\
\hline $25 a$ & 27.1 & 30.7 & 1 & 24.3 & $5.3 \mathrm{E}-06$ \\
\hline $25 b$ & 58.3 & 58.3 & 1 & 25.6 & $2.8 \mathrm{E}-06$ \\
\hline 26 & 19.3 & 22.3 & 4 & 29.8 & $3.4 \mathrm{E}-07$ \\
\hline 27 & 36.1 & 36.2 & 2 & 30.8 & $2.1 \mathrm{E}-07$ \\
\hline $29 a$ & 7.3 & 9.1 & 2 & 65.7 & $5.4 \mathrm{E}-15$ \\
\hline $29 b$ & 43.8 & 44.3 & 4 & 27.1 & $1.3 \mathrm{E}-06$ \\
\hline
\end{tabular}

${ }^{1}$ Regions were defined by grouping SNP located within 4-Mb intervals.

${ }^{2}$ Number of breed $\times$ trait combinations with significant genome-wide results (LRT $>23.6$; nominal $P<7.6 \mathrm{E}-$ 06; Bonferroni corrected $P<0.05$ ); in bold, regions with LRT $>50$ (nominal $P<1.4 \mathrm{E}-11$; Bonferroni corrected $P<9.3 \mathrm{E}-08)$. 
NO, and HO breeds, respectively. In total, 26, 20, and 17 distinct QTL regions, corresponding to 54, 71, and 54 region $\times$ trait combinations, were significant at the genome-wide level in the $\mathrm{MO}, \mathrm{NO}$, and $\mathrm{HO}$ breeds, respectively. The number of QTL acting on PC differed as a function of the breed: 3 QTL in MO $(6 c, 20 b$, and 25b), 6 QTL in NO $(3 b, 6 c, 11 a, 14 a, 20 a$, and 26) and 4 QTL in HO $(6 c, 14 a, 20 a$, and 29b), the 6c QTL being the only one common to all 3 breeds. All these QTL explained, respectively, 19.6, 26.5, and $21.5 \% \mathrm{GV}$ of PC. For protein composition traits, 6 regions were common to the 3 breeds $(2 c, 6 c, 11 c, 14 a, 20 c$, and 29a) and generally affected the same traits, except for the $14 \mathrm{a}$ QTL region that had effects on 10 different traits in the $\mathrm{NO}$ and $\mathrm{HO}$ breeds but only affected one $\mathrm{CN}$ content in MO. The 3 most significant regions, $6 c, 11 c$, and $20 c$, displayed high LRT values in all 3 breeds (Figure 2) and mainly affected $\kappa$-CN $(11,16$, and $20 \% \mathrm{GV}$ in MO, $\mathrm{NO}$, and $\mathrm{HO}$, respectively), $\beta$-LG $(46,41$, and $51 \% \mathrm{GV})$, and $\alpha$-LA $(32,25$, and $26 \% \mathrm{GV})$ contents, expressed as a percentage of protein, respectively. The 11c QTL had the strongest effects, with huge LRT values ranging from 1,563 to 1,866 . Some QTL regions were found in only 1 breed. Breed-specific regions generally had weaker effects than shared regions, except for $6 a \mathrm{QTL}$, which explained about $31 \% \mathrm{GV}$ of $\alpha_{\mathrm{S} 1} \mathrm{CN}$ (as a percentage of protein) in $\mathrm{HO}$ and had no significant effect in $\mathrm{MO}$ and $\mathrm{NO}$ cows.
Compared with proteins expressed as a percentage of milk, the number of significant results found for proteins expressed as a percentage of protein was higher in MO (33 vs. 18 region $\times$ trait combinations) and more similar in NO (30 vs. 35 region $\times$ trait combinations) and $\mathrm{HO}$ (27 vs. 23 region $\times$ trait combinations) cows. On average, the total genetic variance explained by all the QTL detected was higher for proteins expressed as a percentage of protein than for proteins expressed as a percentage of milk in MO (39 vs. $26 \% \mathrm{GV}$ ), NO (38 vs. $31 \% \mathrm{GV}$ ), and $\mathrm{HO}$ (43 vs. $26 \% \mathrm{GV}$ ) cows.

For each of the 6 milk protein fractions included in this study, up to 9 QTL regions were identified $(2-7$ as a percentage of milk and $2-8$ as a percentage of protein). Depending on the protein and the unit of expression, the percentage of genetic variance explained by all the QTL detected ranged from 16 to $51 \%$ in MO, 26 to $43 \%$ in NO, and 19 to $55 \%$ in $\mathrm{HO}$ animals. As a percentage of protein, $\beta-\mathrm{LG}$ had the highest proportion of total genetic variance explained by the QTL $(51,43$, and $55 \%$ in the $\mathrm{MO}, \mathrm{NO}$, and $\mathrm{HO}$ breeds, respectively), and it had the smallest number of QTL detected (2 in each breed). It is worth noting that for this trait, the 2 QTL detected co-localized (6c and 11c) in the 3 breeds. The protein with the smallest proportion of genetic variance explained by the QTL was $\beta$-CN expressed as a percentage of milk $(16,26$, and $19 \% \mathrm{GV}$ in the MO, $\mathrm{NO}$, and HO breeds).

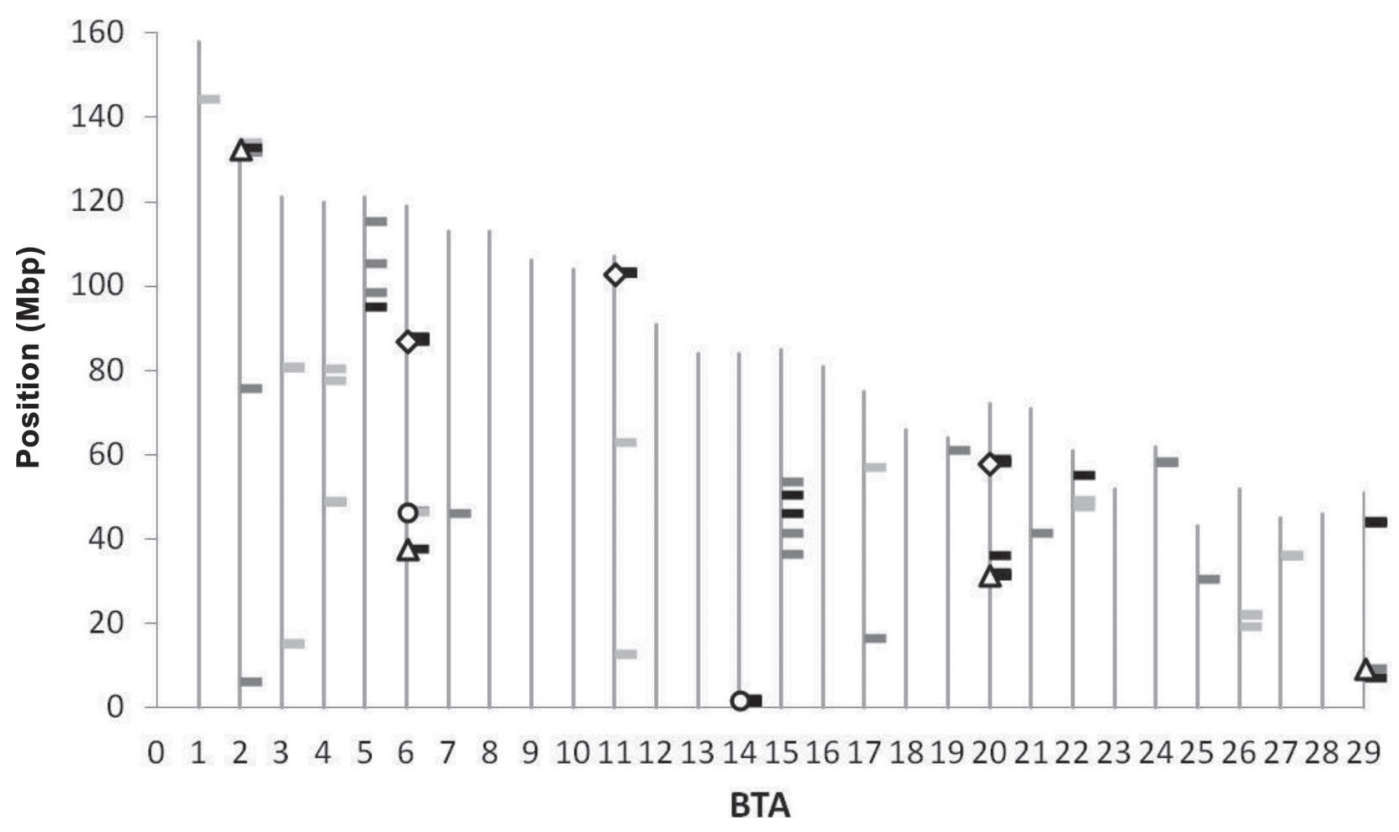

Figure 1. Genomic locations of QTL detected with likelihood-ratio test statistic (LRT) >23.6 in Holstein (black dash), Montbéliarde (dark gray dash), and Normande (light gray dash) breeds. QTL with LRT $>50$ found in 3 breeds $(\diamond), 2$ breeds $(\bigcirc)$, or 1 breed $(\Delta)$. 
GENOME SCAN OF COW MILK PROTEIN COMPOSITION

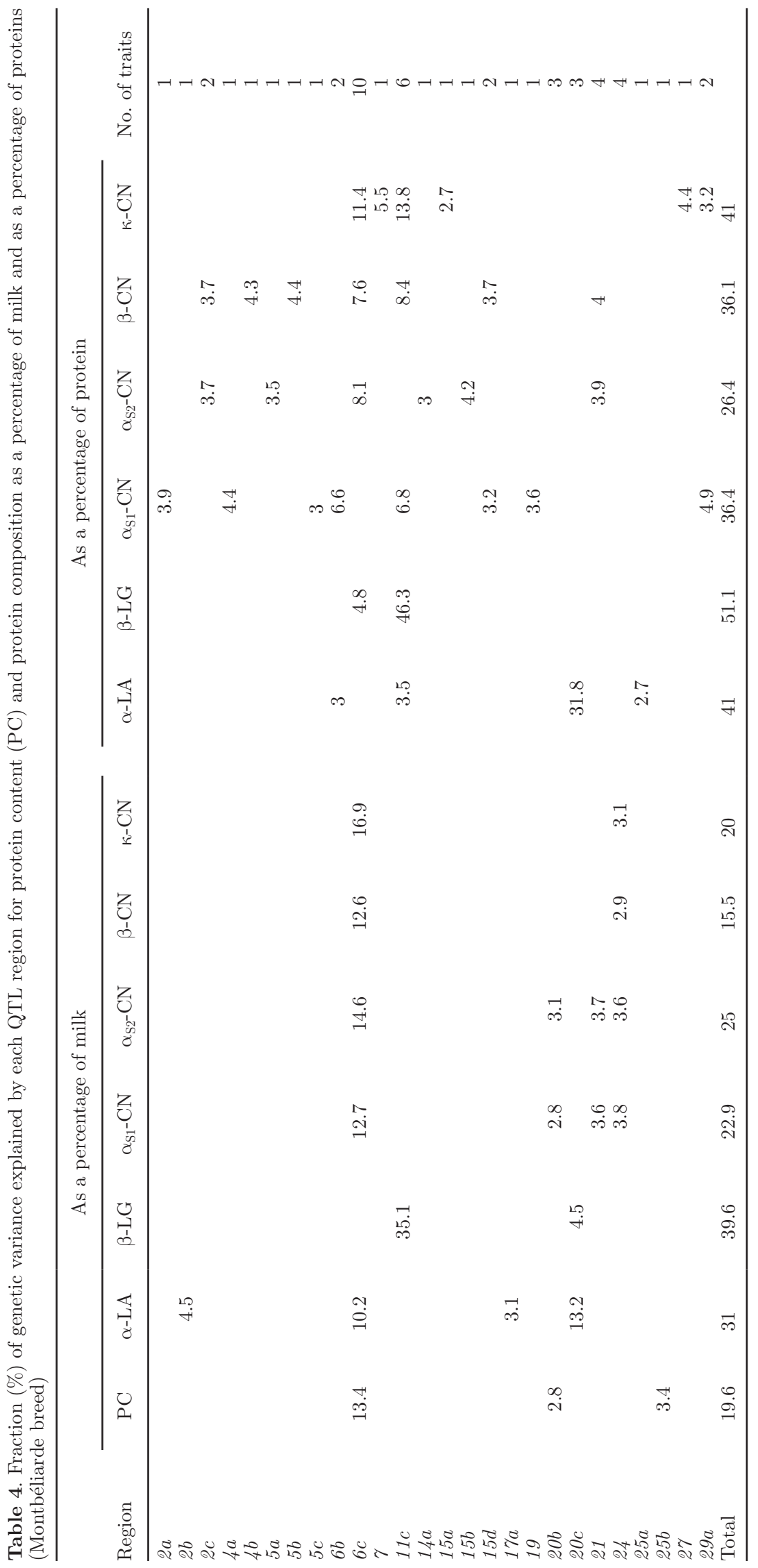


SANCHEZ ET AL.

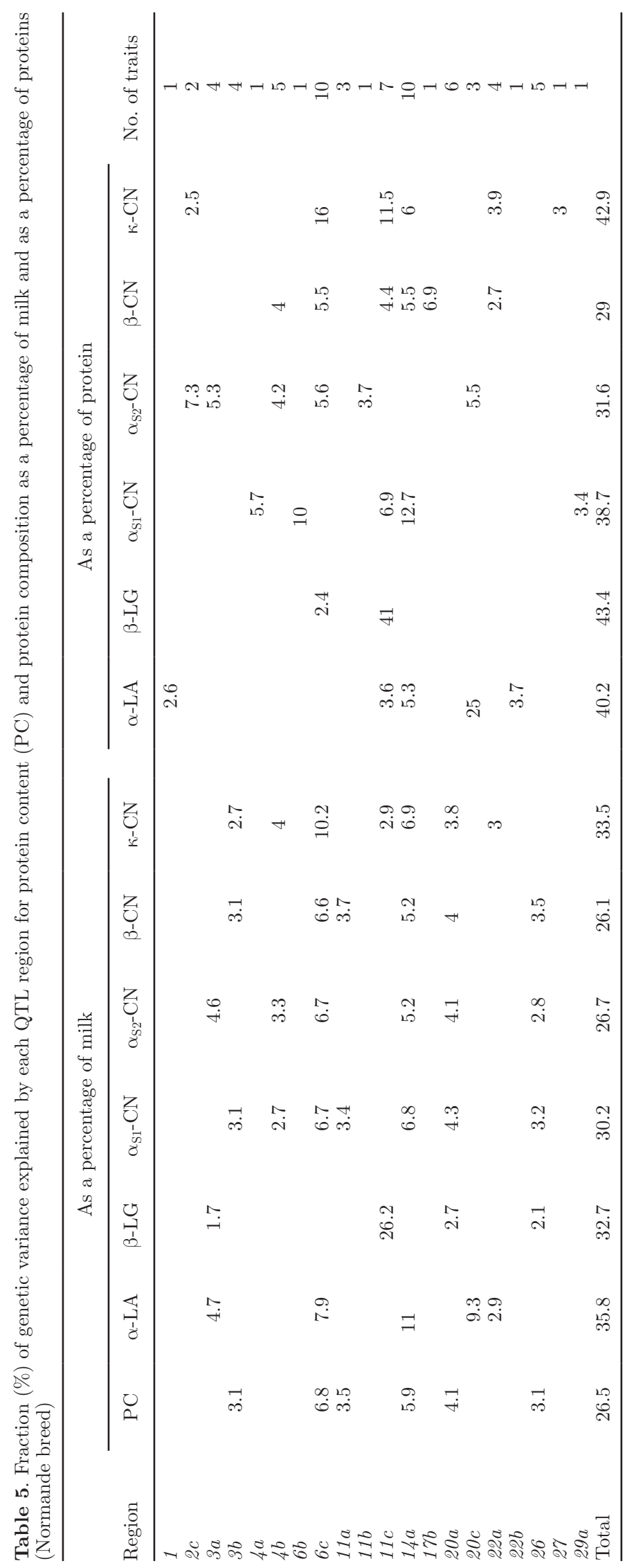




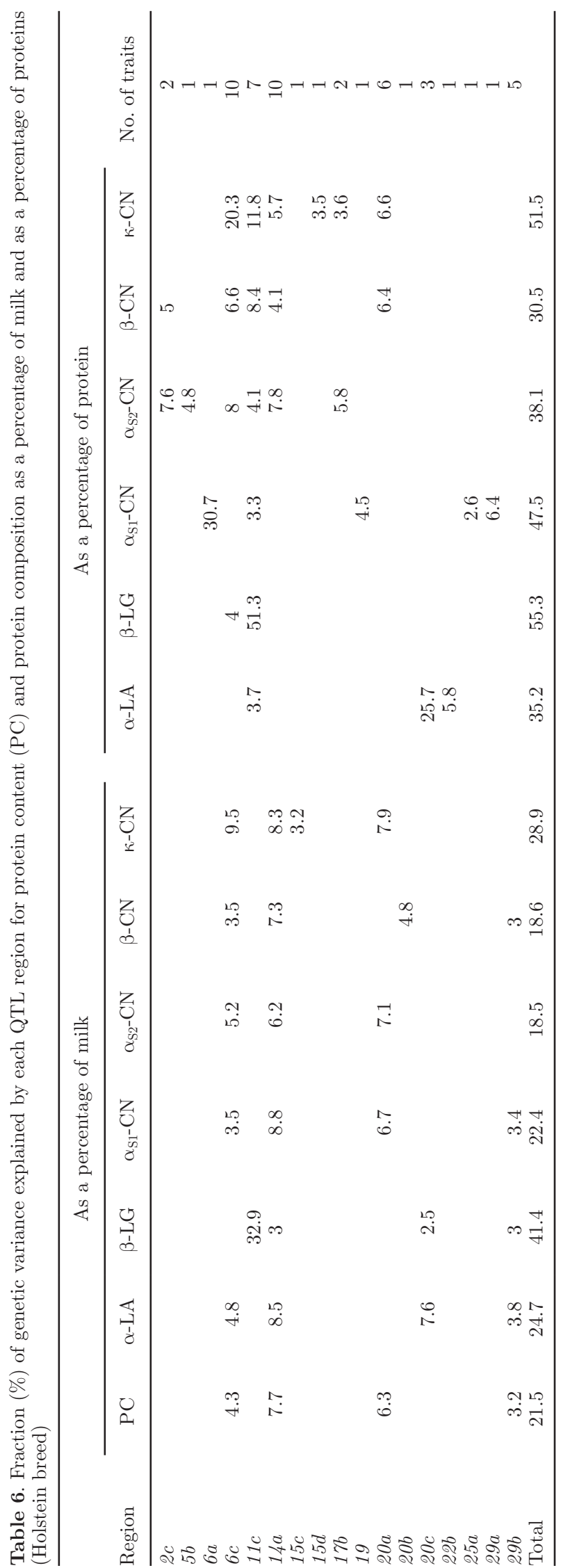

\section{DISCUSSION}

In this study, we report the results of a genome-wide scan of milk protein composition predicted from MIR spectra. It was conducted using 7,654 genotyped cows from the 3 main French dairy breeds. Numerous QTL regions (39 distinct regions in total: $17-26$ per breed) were detected for protein composition, out of which 9 showed highly significant effects on protein composition, expressed as a proportion of total protein (percentage of protein) or milk (percentage of milk). In addition to genetic parameter results (Brochard et al., 2013), these QTL detection results confirmed that MIR predictions were accurate enough for genetic investigations. Indeed, repeated test-day records ( 6 on average per cow) compensated for the moderate MIR prediction accuracy of some proteins. The QTL detected explained a higher proportion of genetic variance for proteins expressed as a percentage of protein than as a percentage of milk. For instance, the 11c QTL region had significant effects on only 1 trait as a percentage of milk ( $\beta-\mathrm{LG}$ ) but affected almost all proteins as a percentage of protein. In addition, some QTL regions presented significant results for traits expressed either as a percentage of protein or as a percentage of milk. Most previous studies in the literature on milk protein composition were performed on traits expressed as a percentage of protein, particularly because protein composition as a percentage of protein is more directly linked to traits of interest, such as the ratio of $\mathrm{CN}$ to total proteins affecting cheese yield (Wedholm et al., 2006). However, correlations among proteins are artificially increased and tend to be negative when they are expressed as a proportion of total proteins because their sum is fixed at 100\% (Brochard et al., 2013). Analyses of proteins as a percentage of milk should therefore enable us to better understand the underlying biological mechanisms because no artificial correlations exist among these traits.

The number of QTL detected, and the magnitude of their effects, were in agreement with the moderate to high heritability estimates $\left(h^{2}\right)$ obtained in the 3 breeds: $0.27<h^{2}<0.86$ (Brochard et al., 2013). Moreover, these results were in agreement with the QTL results previously reported by Schopen et al. (2011) on protein contents estimated by capillary zone electrophoresis in 1,713 Dutch Holstein-Friesian cows. The authors highlighted several QTL throughout the genome, which included 3 with major effects located on BTA6, BTA11, and BTA14 explaining more than $10 \%$ of the genetic variance of the trait and 2 other QTL located on BTA5 and BTA29 with more moderate effects and explaining 5 to $10 \%$ of the genetic variance of the trait. All those QTL regions, except the one on BTA5, were also found in this study and corresponded 


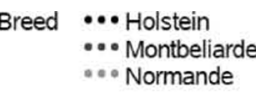

1) BTA6: $\alpha_{s 1}$-casein

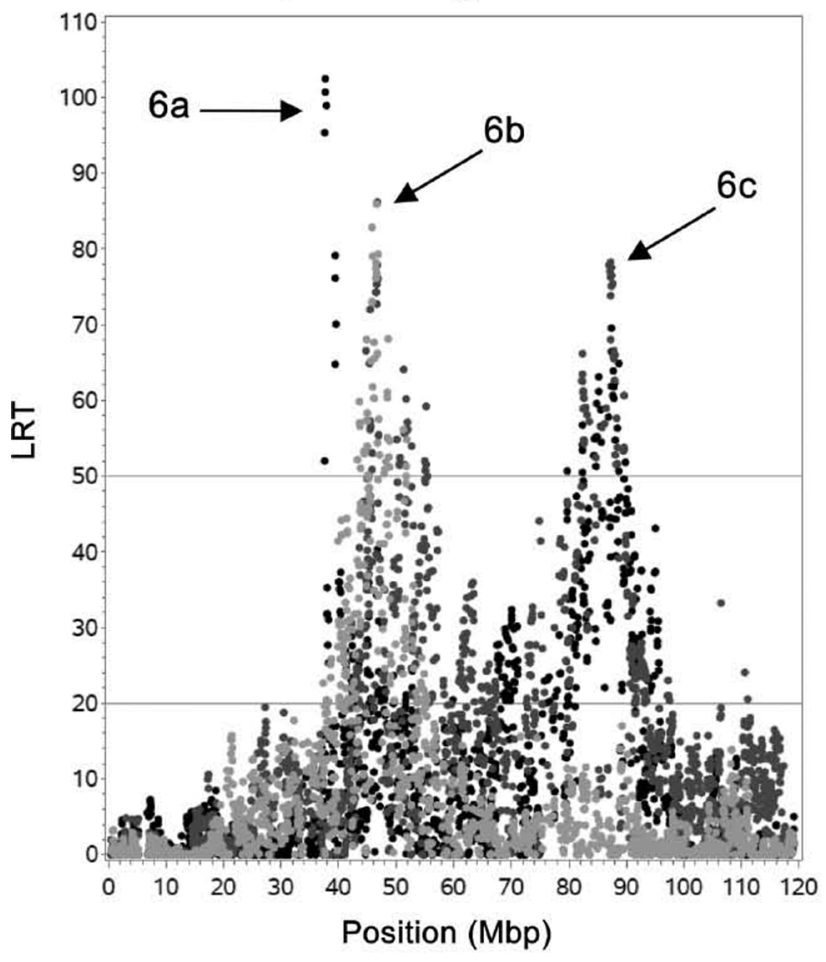

3) BTA11: $\beta$-lactoglobulin

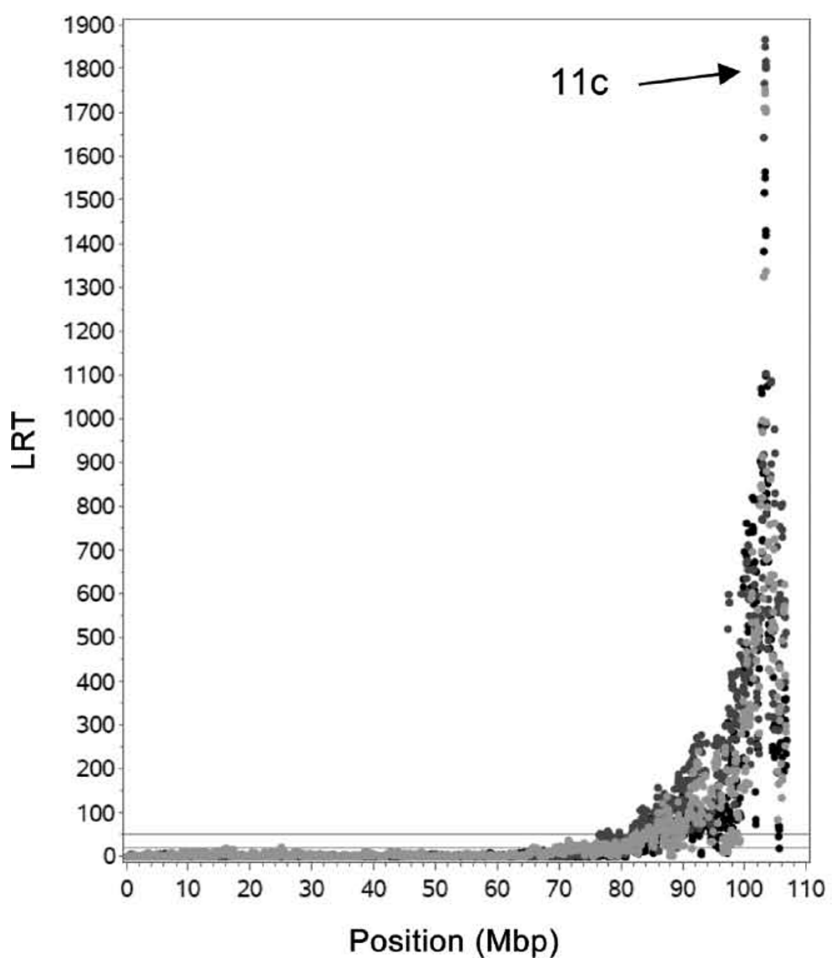

2) BTA6: $\kappa-c a s e i n$

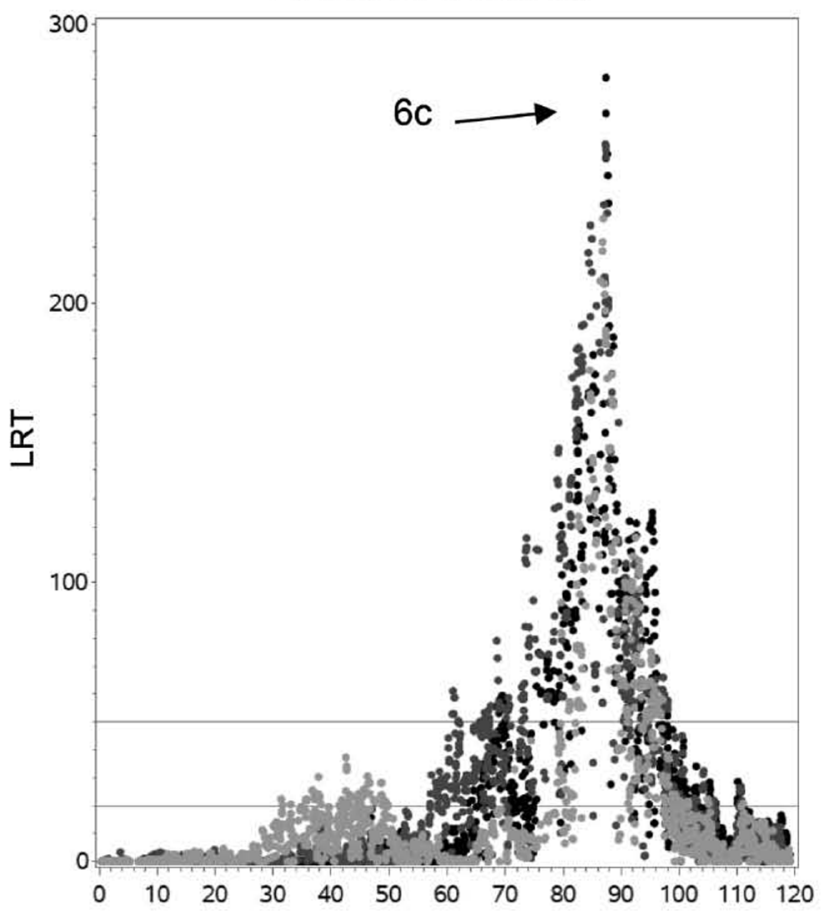

4) BTA20: $\alpha$-lactalbumin

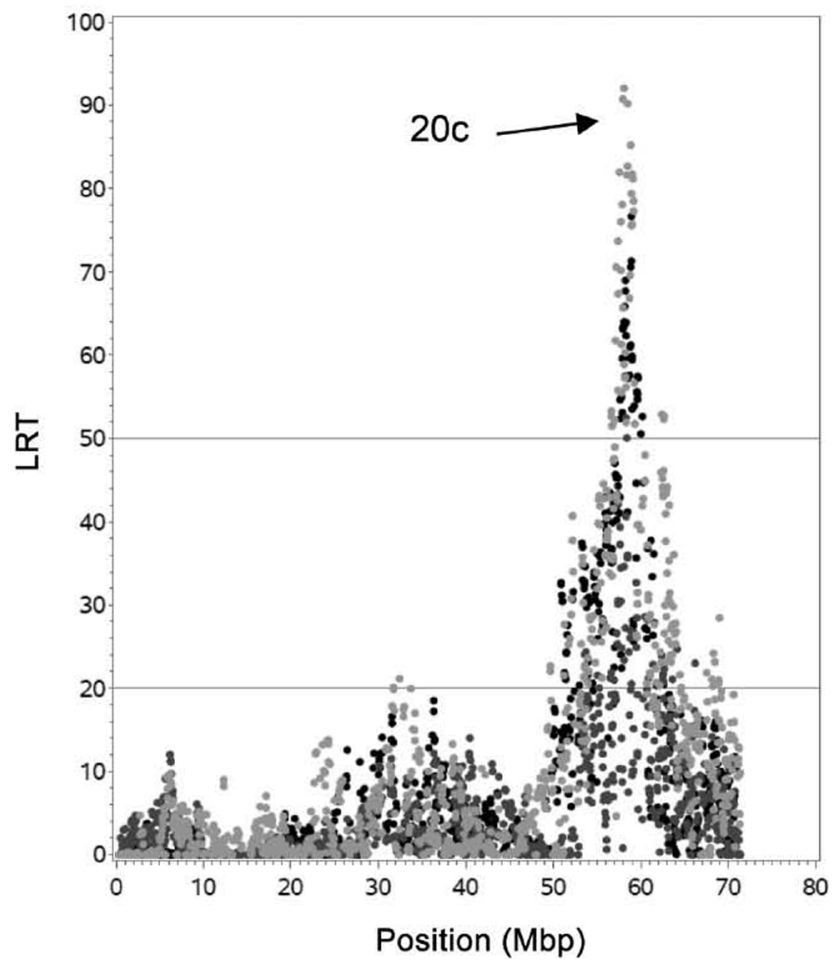

Figure 2. Likelihood ratio test (LRT) values plotted against SNP positions on BTA6 (1 and 2), BTA11 (3), and BTA20 (4) for protein contents expressed as a percentage of protein in Holstein, Montbéliarde, and Normande breeds. 
to the $6 c, 11 c, 14 a$, and $29 b$ QTL, respectively. Another study tested the association between 53 SNP located within or close to milk protein genes (BTA5, BTA6, and BTA11) and the milk protein profile measured by reverse-phase HPLC in purebred Holstein and (Holstein $\times$ Jersey) $\times$ Holstein backcross cows (Huang et al., 2012). Those authors found SNP that significantly explained a high percentage of the phenotypic variance of milk protein composition on BTA6 and BTA11 but not on BTA5, which is consistent with results found in the present study. In addition, 6 other QTL $(2 c, 6 a$, $6 b, 20 a, 20 c$, and 29a) with effects ranging from 5 to $32 \%$ of the genetic variance of the trait were detected in our study. Schopen et al. (2011) also reported the $6 b$ and 20a QTL as having weaker effects (about 3\%), but they did not detect the 2c,6a, 20c, and 29a QTL. This was not surprising with respect to $2 c$ and $29 a$ because these 2 QTL were only found in the NO population. However, it was more unexpected for $6 a$ and $20 c$, which exhibited highly significant effects in $\mathrm{HO}$ cows and explained 31 and $26 \%$ of the genetic variance of $\alpha_{S_{1}-} \mathrm{CN}$ and $\alpha$-LA, respectively. The 20c QTL located at 58 to $59 \mathrm{Mbp}$ was highly significant and explained 32,25 , and $26 \%$ of the genetic variance of the $\alpha$-LA content in the $\mathrm{MO}, \mathrm{NO}$, and $\mathrm{HO}$ breeds, respectively. Microsatellite marker-based associations have been previously reported between PC and this region (Ashwell et al., 2004; Bagnato et al., 2008) and more recently with milk yield using SNP from the Illumina BovineHD BeadChip (Kemper et al., 2015), but the current report is the first time this region has been associated with milk protein composition.

The estimates of variance components were quite high. Because they were determined one by one in a one-QTL model, we cannot exclude the possibility that they were somewhat overestimated. Nevertheless, individual milk protein fractions are intermediate phenotypes compared, for example, with protein content, and QTL effects can be expected to be more marked.

Among the numerous QTL detected during our study, several were of particular interest because they had strong effects on milk protein composition, they were found in several breeds, or both factors were present. Identifying the causal mutations responsible for these effects could therefore be valuable for improving these traits through genomic selection. In each of the $6 a, 6 c, 11 c, 14 a$, and 20a QTL regions, candidate mutations had previously been associated with protein content in the literature. For these QTL regions, we tested whether the mutations previously described in the literature might be responsible for the effects observed in the PFL populations. To achieve this, we took advantage of the genome sequence of some PFL bulls from the 1,000 bull genomes project to perform concordance analyses between the QTL statuses and candidate mutation genotypes of the bulls.

\section{6a QTL and the ABCG2 Gene}

The 6a QTL, located at around 37.7 Mbp, explained almost one-third of the genetic variance of $\alpha_{\mathrm{S}^{-}} \mathrm{CN}$ in HO cows. The Y581S mutation in the ABCG2 gene, located about $300 \mathrm{kbp}$ downstream of the $6 a$ QTL region, had previously been proposed as the causal mutation for milk yield and composition in Holstein cows. All the PFL bulls sequenced were homozygous A/A at this locus, whereas 6 were homozygous and 6 were heterozygous for the $6 a$ QTL. The Y581S mutation in the $A B C G 2$ gene was not responsible for the effects observed in our study. Nevertheless, the most significant SNP in this region was located at $37,653,391 \mathrm{bp}$; that is, between the HERC3 (45 kbp downstream) and PIGY (24 kbp upstream) genes. A nearby SNP located at $37,631,640 \mathrm{bp}$ on the BovineSNP50 BeadChip had previously been found to be associated with the milk protein percentage in Chinese Holstein cows (Jiang et al., 2010) and this was confirmed subsequently in the same population using a multiple SNP approach (Fang et al., 2014). This SNP was not tested during our study because it failed the quality control filters in the PFL HO population.

\section{6b QTL and CN Genes}

The locations of the most significant SNP in the $6 c$ QTL region ranged from 86.9 to $88.2 \mathrm{Mbp}$, depending on the trait and the breed. Major effects were found for all the analyzed traits expressed as a percentage of milk or as a percentage of protein in the 3 breeds and were particularly high for $\mathrm{CN}$ contents. The $6 c$ region includes genes encoding for caseins that are tightly linked in a 250-kb cluster (CSN1S1, CSN2, CSN1S2, and $C S N 3$ ). The genotypes for 5 known polymorphisms in CSN1S1 $(87,157,262)$, CSN2 $(87,181,501$ and $87,181,619)$, and CSN3 $(87,390,612$ and $87,390,632)$ were tested in the PFL bulls (7 were heterozygous and 5 were homozygous for the QTL) and none of them was concordant with the QTL statuses. Nevertheless, the effects of these genes cannot be discarded because of the presence of different haplotypes formed by several polymorphisms in strong linkage disequilibrium in this region (Martin et al., 2002). Concordance analysis is known to be sensitive to multiple causal variants, and this hypothesis cannot be excluded in this case. 


\section{1c $Q T L$ and the LGB Gene}

In the $11 c$ QTL region, a single SNP located at position 103,289,035 displayed the most significant effects in the $\mathrm{MO}, \mathrm{NO}$, and $\mathrm{HO}$ breeds during QTL detection analyses (41 to $51 \%$ of the genetic variance of $\beta$-LG content). It was in full linkage disequilibrium with the 2 mutations described by Ganai et al. (2009) as the causal genetic polymorphisms of $\beta$-LG protein variants $\mathrm{A}$ and $\mathrm{B}$ in the $L G B$ gene $(103,303,475$ and $103,304,757$ $\mathrm{bp}$ ) in all the MO, NO, and $\mathrm{HO}$ bulls tested. Genotypes for the QTL and causal genetic polymorphisms were therefore perfectly concordant for all the bulls tested (7 were heterozygous and 3 were homozygous for the QTL).

\section{4a QTL and the DGAT1 Gene}

The K232A DGAT1 polymorphism on BTA14 (Grisart et al., 2002) was investigated to explain the effects of the $14 a$ QTL region. Only 1 (HO) of the 13 tested bulls was found to be heterozygous for the QTL in the centromeric region of BTA14. However, reaching any conclusion was not possible because of the very poor sequence quality in this region for several of the bulls tested and particularly for the HO bull heterozygous for the QTL. Nevertheless, the very low frequency of K232A in MO and NO animals allowed us to hypothesize that it could not explain the QTL in these 2 breeds.

\section{0b QTL and the GHR Gene}

The 20b QTL was located between 31.6 and 32.1 Mbp and had effects in both the NO and HO breeds. In NO cows, these effects were moderate $(3-4 \%$ of genetic variance) and only found with respect to the protein composition expressed as a percentage of milk, whereas in $\mathrm{HO}$ cows the effects concerned both protein composition as a percentage of milk (6-8\% of genetic variance) and some $\mathrm{CN}$ contents as a percentage of protein $(\beta-$ and $\kappa-\mathrm{CN})$. In both breeds, the effects on $\mathrm{PC}$ were significant (4 and $6 \%$ of genetic variance in the $\mathrm{NO}$ and $\mathrm{HO}$ breeds, respectively). In this QTL region, the F279Y mutation in the GHR gene at position 31,909,478 had previously been found to affect PC (Blott et al., 2003). Two PFL bulls were heterozygous and 9 were homozygous for the QTL, and genotypes at this site were concordant with their QTL status, suggesting that the mutation in the GHR gene might explain the effects detected in our study.

\section{CONCLUSIONS}

The identification of numerous QTL with marked effects on protein composition predicted from MIR spectra could help selection of these traits from routinely collected MIR spectra. The accuracy of MIR predictions remained moderate, but it was compensated for by the multiplicity of test-day measures and the strong effect of the QTL. The PFL population, consisting of 2,208 to 2,773 phenotyped and genotyped cows depending on the breed, represents a first reference population for genomic selection. In the near future, MIR spectra combined with large-scale cow genotyping will enable the rapid development of such reference populations. Therefore, if a clear breeding objective were defined, genomic selection could easily be implemented to target these traits. Moreover, through the use of whole-genome sequences during our study, 2 known mutations ( $L G B$ and $G H R$ ) were confirmed to be strong candidates responsible for the QTL effects, and another one (ABCG2) was discarded. For all the other regions, association studies applied to cow wholegenome sequences imputed from BovineSNP50 BeadChip genotypes (via BovineHD BeadChip genotypes) are expected to identify new candidate mutations for milk protein composition.

\section{ACKNOWLEDGMENTS}

The PhénoFinLait project has received financial support from Agence Nationale de le Recherche (ANR-08-GANI-034 Lactoscan), APIS-GENE, Compte d'Affectation Spéciale Développement Agricole et Rural, Centre National Interprofessionnel de l'Economie Laitière, FranceAgriMer, France Génétique Elevage, and the French Ministry of Agriculture. The authors thank the breeders who participated in PhénoFinLait; colleagues from Institut de l'Elevage and INRA who designed and coordinated farm samples and data collection; the partners of the project, laboratories, manufacturers, and DHI organizations that provided data; and the members of the PhénoFinLait scientific committee who advised and managed this work. The whole genome sequences of bulls were funded by the ANR CartoSeq project (ANR-10-GENM-0018) and APIS-GENE.

\section{REFERENCES}

Ashwell, M. S., D. W. Heyen, T. S. Sonstegard, C. P. Van Tassell, Y. Da, P. M. VanRaden, M. Ron, J. I. Weller, and H. A. Lewin. 2004. Detection of quantitative trait loci affecting milk production, health, and reproductive traits in Holstein cattle. J. Dairy Sci. $87: 468-475$. 
Bagnato, A., F. Schiavini, A. Rossoni, C. Maltecca, M. Dolezal, I. Medugorac, J. Sölkner, V. Russo, L. Fontanesi, A. Friedmann, M. Soller, and E. Lipkin. 2008. Quantitative trait loci affecting milk yield and protein percentage in a three-country Brown Swiss population. J. Dairy Sci. 91:767-783.

Blott, S., J. J. Kim, S. Moisio, A. Schmidt-Küntzel, A. Cornet, P. Berzi, N. Cambisano, C. Ford, B. Grisart, D. Johnson, L. Karim, P. Simon, R. Snell, R. Spelman, J. Wong, J. Vilkki, M. Georges, F. Farnir, and W. Coppieters. 2003. Molecular dissection of a quantitative trait locus: A phenylalanine-to-tyrosine substitution in the transmembrane domain of the bovine growth hormone receptor is associated with a major effect on milk yield and composition. Genetics 163:253-266.

Boichard, D., F. Guillaume, A. Baur, P. Croiseau, M. Rossignol, M. Boscher, T. Druet, L. Genestout, J. Colleau, L. Journaux, V. Ducrocq, and S. Fritz. 2012. Genomic selection in French dairy cattle. Anim. Prod. Sci. 52:115-120.

Bonfatti, V., A. Cecchinato, L. Gallo, A. Blasco, and P. Carnier. 2011a. Genetic analysis of detailed milk protein composition and coagulation properties in Simmental cattle. J. Dairy Sci. 94:5183-5193.

Bonfatti, V., G. Di Martino, and P. Carnier. 2011b. Effectiveness of mid-infrared spectroscopy for the prediction of detailed protein composition and contents of protein genetic variants of individual milk of Simmental cows. J. Dairy Sci. 94:5776-5785.

Boussaha, M., D. Esquerre, J. Barbieri, A. Djari, A. Pinton, R. Letaief, G. Salin, F. Escudie, A. Roulet, S. Fritz, F. Samson, C. Grohs, M. Bernard, C. Klopp, D. Boichard, and D. Rocha. 2015. Genomewide study of structural variants in bovine Holstein, Montbeliarde and Normande dairy breeds. PLoS ONE 10:e0135931.

Brochard, M., M. P. Sanchez, A. Govignon-Gion, M. Ferrand, M. Gelé, D. Pourchet, G. Miranda, P. Martin, and D. Boichard. 2013. Paramètres génétiques pour la composition protéique du lait dans 3 races bovines. Page 158 in Rencontres autour des Recherches sur les Ruminants Vol. 20, Paris, France. INRA, Paris, France.

Daetwyler, H. D., A. Capitan, H. Pausch, P. Stothard, R. Van Binsbergen, R. F. Brøndum, X. Liao, A. Djari, S. Rodriguez, C. Grohs, D. Esquerré, O. Bouchez, M. N. Rossignol, C. Klopp, D. Rocha, S. Fritz, A. Eggen, P. J. Bowman, D. Coote, A. J. Chamberlain, C. P. VanTassell, I. Hulsegge, M. E. Goddard, B. Guldbrandtsen, M. S. Lund, R. F. Veerkamp, D. Boichard, R. Fries, and B. J. Hayes. 2014. Whole-genome sequencing of 234 bulls facilitates mapping of monogenic and complex traits in cattle. Nat. Genet. 46:858-865. http://dx.doi.org/10.1038/ng.3034.

Druet, T., S. Fritz, M. Boussaha, S. Ben-Jemaa, F. Guillaume, D. Derbala, D. Zelenika, D. Lechner, C. Charon, D. Boichard, I. G. Gut, A. Eggen, and M. Gautier. 2008. Fine mapping of quantitative trait loci affecting female fertility in dairy cattle on BTA03 using a dense single-nucleotide polymorphism map. Genetics 178:22272235 .

Druet, T., and M. Georges. 2010. A hidden Markov model combining linkage and linkage disequilibrium information for haplotype reconstruction and quantitative trait locus fine mapping. Genetics 184:789-798.

Ducrocq, V. 1998. Genekit, BLUP software. June 2011 version ed. INRA GABI, Jouy-en-Josas, France.

Fang, M., W. Fu, D. Jiang, Q. Zhang, D. Sun, X. Ding, and J. Liu. 2014. A multiple-SNP approach for genome-wide association study of milk production traits in Chinese Holstein cattle. PLoS ONE 9:e99544.

Ferrand, M., G. Miranda, S. Guisnel, H. Larroque, O. Leray, F. Lahalle, M. Brochard, and P. Martin. 2012. Determination of protein composition in milk by mid-infrared spectrometry. Pages $41-45$ in Proc. International Strategies and New Developments in Milk Analysis. VI ICAR Reference Laboratory Network Meeting, Cork, Ireland. ICAR, Rome, Italy.

Ganai, N. A., H. Bovenhuis, J. A. van Arendonk, and M. H. Visker. 2009. Novel polymorphisms in the bovine beta-lactoglobulin gene and their effects on beta-lactoglobulin protein concentration in milk. Anim. Genet. 40:127-133.
Gebreyesus, G., M. S. Lund, L. Janss, N. A. Poulsen, L. B. Larsen, H. Bovenhuis, and A. J. Buitenhuis. 2016. Short communication: Multi-trait estimation of genetic parameters for milk protein composition in the Danish Holstein. J. Dairy Sci. 99:2863-2866.

Gelé, M., S. Minery, J. M. Astruc, P. Brunschwig, M. Ferrand, G. Lagriffoul, H. Larroque, J. Legarto, P. Martin, G. Miranda, I. Palhière, P. Trossat, and M. Brochard. 2014. Phénotypage et génotypage à grande échelle de la composition fine des laits dans les filières bovine, ovine et caprine. Prod. Anim. 27:255-268.

Grignola, F. E., I. Hoeschele, Q. Zhang, and G. Thaller. 1996. Mapping quantitative trait loci in outcross populations via residual maximum likelihood. II. A simulation study. Genet. Sel. Evol. 28:491-504.

Grisart, B., W. Coppieters, F. Farnir, L. Karim, C. Ford, P. Berzi, N. Cambisano, M. Mni, S. Reid, P. Simon, R. Spelman, M. Georges, and R. Snell. 2002. Positional candidate cloning of a QTL in dairy cattle: Identification of a missense mutation in the bovine DGAT1 gene with major effect on milk yield and composition. Genome Res. 12:222-231.

Huang, W., F. Peñagaricano, K. R. Ahmad, J. A. Lucey, K. A. Weigel, and H. Khatib. 2012. Association between milk protein gene variants and protein composition traits in dairy cattle. J. Dairy Sci. 95:440-449.

Jiang, L., J. Liu, D. Sun, P. Ma, X. Ding, Y. Yu, and Q. Zhang. 2010. Genome wide association studies for milk production traits in Chinese Holstein population. PLoS ONE 5:e13661.

Kemper, K. E., C. M. Reich, P. J. Bowman, C. J. Vander Jagt, A. J. Chamberlain, B. A. Mason, B. J. Hayes, and M. E. Goddard. 2015. Improved precision of QTL mapping using a nonlinear Bayesian method in a multi-breed population leads to greater accuracy of across-breed genomic predictions. Genet. Sel. Evol. 47:29.

Martin, P., M. Szymanowska, L. Zwierzchowski, and C. Leroux. 2002. The impact of genetic polymorphisms on the protein composition of ruminant milks. Reprod. Nutr. Dev. 42:433-459.

Meuwissen, T. H., A. Karlsen, S. Lien, I. Olsaker, and M. E. Goddard. 2002. Fine mapping of a quantitative trait locus for twinning rate using combined linkage and linkage disequilibrium mapping. Genetics 161:373-379.

Meuwissen, T. H., and M. E. Goddard. 2000. Fine mapping of quantitative trait loci using linkage disequilibria with closely linked marker loci. Genetics 155:421-430.

Misztal, I., T. Tsuruta, B. Strabel, B. Auvray, and T. Druet. 2002. BLUPF90 and related programs (BGF90). Pages 21-22 in Proc. 7th World Congress on Genetics Applied to Livestock Production. Montpellier, France. Editions Quae, Versailles, France.

Schopen, G. C., J. M. Heck, H. Bovenhuis, M. H. Visker, H. J. van Valenberg, and J. A. van Arendonk. 2009. Genetic parameters for major milk proteins in Dutch Holstein-Friesians. J. Dairy Sci. 92:1182-1191.

Schopen, G. C., M. H. Visker, P. D. Koks, E. Mullaart, J. A. van Arendonk, and H. Bovenhuis. 2011. Whole-genome association study for milk protein composition in dairy cattle. J. Dairy Sci. 94:3148-3158.

van den Berg, I., S. Fritz, S. Rodriguez, D. Rocha, M. Boussaha, M. S. Lund, and D. Boichard. 2014. Concordance analysis for QTL detection in dairy cattle: A case study of leg morphology. Genet. Sel. Evol. 46:31.

Wedholm, A., L. B. Larsen, H. Lindmark-Månsson, A. H. Karlsson, and A. Andrén. 2006. Effect of protein composition on the cheesemaking properties of milk from individual dairy cows. J. Dairy Sci. 89:3296-3305.

Zimin, A., A. Delcher, L. Florea, D. Kelley, M. Schatz, D. Puiu, F. Hanrahan, G. Pertea, C. Van Tassell, T. Sonstegard, G. Marcais, M. Roberts, P. Subramanian, J. Yorke, and S. Salzberg. 2009. A whole-genome assembly of the domestic cow, Bos taurus. Genome Biol. 10:R42. 